\title{
Key Factors Determining the Ethnocentric Tendencies of Consumers in Serbia
}

DOI: 10.7595/management.fon.2017.0028

\begin{abstract}
Ethnocentric behaviour of consumers is related to the attitude and intentions of consumers when deciding upon purchasing a product, i.e., it is such a kind of behaviour which implies giving priority to purchasing domestic rather than foreign products. The results of a large number of studies show that not all consumers are equally ethnocentric. Therefore, it is of utmost significance to realize that consumers rely on various signals and make different decisions depending on their inclinations towards consumer ethnocentrism. The aim of this paper is to examine the influence and interaction of demographic characteristics of respondents in Serbia on consumer ethnocentrism. Several statistical techniques that provided support during the testing of research hypotheses have been applied in the preparation of this paper. We used nonparametric techniques (Mann-Whitney $U$ test and Kruskal-Wallis test). The results indicate that men are more ethnocentric than women, as well as persons with lower level of education than those with higher level of education. Also, the results have shown that respondents who achieve the highest level of income are not ethnocentric in the least. In addition, it has been established that there is no statistically significant impact of the criteria of the year on the level of consumer ethnocentrism. The research results provide useful information for marketers and managers of companies that currently operate or are planning to enter Serbian market in the forthcoming period. Another great benefit is reflected in the fact that these results draw the managers' attention to the fact which consumer groups are the most ethnocentric and thus allow the creation of high quality strategies.
\end{abstract}

Keywords: ethnocentrism, consumer behaviour, demographic characteristics

JEL Classification: M31, D12, J10

\section{Introduction}

Contemporary market operations and conditions dictated by the market require companies to carry out permanent monitoring of all variables that are of interest to their normal functioning, survival, and development. Companies are facing the task of monitoring changes taking place on the market with the most significant among them being those related to consumer behaviour. Through their behaviour (purchases), consumers verify and confirm a company's efforts so it is essential to devote close attention to their research. In the era of globalization and increasing competition, consumers around the world are provided with a large number of both domestic and imported products and services. Therefore, it is of utmost importance to be familiar with their attitudes towards imported goods and services, i.e., it is an imperative for all companies to observe the level of consumer ethnocentrism.

Given that conceptualization and measurement of ethnocentrism (as observed from the aspect of sociology and psychology) are irrelevant to the measurement of ethnocentrism in the context of consumption, Shimp and Sharma (1987) introduced the construct of consumer ethnocentrism. The general definition of consumer ethnocentrism refers to the phenomenon according to which consumers prefer local products or are biased against imported ones (LeVine \& Campbell, 1972). Consumer ethnocentrism can be interpreted 
through observing import as something bad, not only because it is unpatriotic, but because it is harmful to the economy and leads to job loss (Kucukemiroglu, 1999). Shimp and Sharma (1987) noted that consumers tend to favor domestic products from their home country even when they do not perceive them as superior. In this way, ethnocentric consumers want to contribute to economic prosperity and thus the overall political, social, and economic development of the country. It is often recognized that during periods of economic crisis ethnocentric behaviour of consumers is recognized as socially acceptable and desirable (Marinkovic et al., 2011). Ethnocentric consumers do not need any interventions by the state to act in such a manner (Veljkovic, 2009). Ethnocentric consumers are also willing to ignore the amount of their expenditure in order to purchase a product of domestic origin (Beslagic, 2015).

For years, numerous studies have been conducted with the aim to better grasp the behaviour of ethnocentric consumers. An important contribution to the research of consumer behaviour lies in the development and application of CETSCALE (Consumer Ethnocentric Tendency Scale) (Shimp \& Sharma, 1987), designed to measure the ethnocentric tendencies of consumers, i.e., the tendency of consumers to favour products from their own country over those supplied from other countries. This multi-item scale has been utilized to analyze why some consumers prefer domestically produced goods over imported goods, even when the latter are cheaper and their quality is evidently better (Chendo, 2013). The scale consists of 17 items, where respondents mark their level of agreement via the seven-point Likert scale. Subsequent research carried out by Netemeyer et al. (1991) firmly supported the psychometric characteristics and validity of the scale in 4 different countries: France, Germany, Japan and the USA. The Cronbach's alpha coefficients ranged from 0.91 to 0.95 . This provided strong support to the unidimensionality of CETSCALE, together with the establishment of internal consistency.

\section{Theoretical Framework of the Research}

The success of a marketing model depends on the ability of researchers to identify the variables that cause people to behave differently in the market (Kucukemiroglu, 1999). Demographic dimensions are widely accepted, easily quantified and consumers are effortlessly classified on such basis (Kucukemiroglu, 1999). Despite the importance of consumer ethnocentrism on the one hand and demographic characteristics on the other hand, numerous researchers (Caruana, 1996; Pharr, 2005; Shankarmahesh, 2006) have pointed out that the existing literature dealing with consumer ethnocentrism and the effect of age, gender, and income on consumer ethnocentrism is unclear and conflicting, and represents a research gap. Earlier studies claimed that there was no consensus about how age, gender, and income affected consumer ethnocentrism (Josiassen et al., 2011). Based on theoretical conceptions of authors who have dealt with this topic in the past, this paper will include a formulation of an appropriate research hypothesis. The basic research hypothesis is: $\mathrm{H}_{0}$ : Socio-demographic characteristics of respondents are the key determinants of consumer ethnocentrism.

The literature on consumer ethnocentrism and the impact of age on the level of consumer ethnocentrism actually shows that there are several various influences. Shankarmahesh (2006) lists six studies showing that older consumers are more ethnocentric than the younger ones, together with two studies whose results showed that younger consumers are more ethnocentric than older ones. Several additional studies (Mittal \& Tsiros, 1995) also indicated that younger consumers were more ethnocentric. The results of a research conducted in India (Garg \& Jain, 2016) implied that younger consumers (aged between 18 and 30) were more ethnocentric in comparison to other age groups. The student population (aged between 18 and 25) in the Republic of Serbia generally manifests a moderate level of consumer ethnocentrism, however, with a tendency of increasing in comparison to previous research (Kragulj et al., 2017). On the other hand, Bannister and Saunders (1978) studied the case of consumers from Great Britain and concluded that the respondents' attitudes towards products from their own country became more favorable as the age of respondents increased. That is, older respondents were more likely to prefer products from their home country in comparison to younger respondents. Also, the results of a survey conducted in Moldova demonstrated that older respondents (aged between 46 and 55) showed far more ethnocentric tendencies in comparison with respondents from the 18-25 age category (Cazacu, 2016). Research of this phenomenon on the territory of Serbia in 2015 also showed that older consumers had more ethnocentric tendencies (Gasevic et al., 2015). Also, research results of the level of respondents' consumer ethnocentrism, who are between 18 and 30 years old, on four markets in the Western Balkans (Slovenia, Croatia, and Macedonia) and China have shown that these respondents, regardless of cultural differences, show a low level of consumer ethnocen- 
trism (Raskovic et al., 2016). The assertion that older consumers tend to be more ethnocentric when purchasing products is confirmed by a positive relationship between age and conservatism (Sharma et al., 1995), and age and dogmatism (Anderson \& Cunningham, 1972) where both of the above sociological concepts are deemed as preconditions for consumer ethnocentrism. Based on the aforementioned considerations, the first hypothesis of this research is defined: $\mathrm{H} 1$ : Older consumers are more ethnocentrically oriented in comparison to younger consumers.

There are certain incompliances with regard to the impact of gender as a factor that determines consumer ethnocentrism. The studies that were conducted in Malaysia revealed that Malay married women tended to show higher ethnocentric tendencies in comparison to men (Othman et al., 2008). Women are more likely to manifest behaviour that is socially desirable and in line with expectations of a socially important group, and they are more conservative (Han \& Terpstra, 1988) when compared to men. Conservatism and conformity (Sharma et al., 1995) are the predecessors of consumer ethnocentrism. Other researchers who were involved in the research of consumer ethnocentrism confirmed that male consumers tended to be less ethnocentric compared to women (Balabanis et al., 2001; Good \& Huddleston, 1995; Sharma et al., 1995). Also there is a number of studies where no statistically significant effect of gender differences has been found (Caruana, 1996) and, again, some other studies show that men are more ethnocentric than women (Bannister \& Saunders, 1978). The research of this phenomenon in Serbia in 2015 showed that men were more ethnocentric (Marinkovic et al., 2011, Gasevic et al., 2015, Grubor \& Đokic, 2015). Schooler (1971) and Dornoff et al. (1974) stated that women had a more favourable assessment of products coming from abroad in comparison to men. Based on the previous statements, and primarily relying on the results of the research in Serbia, the following hypothesis is defined: $\mathrm{H} 2$ : Men are more ethnocentric in comparison to women.

In literature, there is no consensus regarding whether an increase in income has a positive or a negative effect on consumer ethnocentrism. While several studies (Caruana, 1996; Sharma et al., 1995) indicated a negative relationship between income and consumer ethnocentrism, some studies (Han \& Terpstra, 1988) suggested that income had no effect, while other (Tan \& Farley, 1987) indicated a positive relationship between income and consumer ethnocentrism. Citing the example of the Czech Republic, Balabanis et al. (2001) indicated that consumers with higher income tended to be more ethnocentric than consumers with lower income. A conceptual argument in favor of the claim that consumers with higher income are less ethnocentric states that consumers earning higher income are more cosmopolitan and travel more. Both of these constructs precede consumer ethnocentrism (Balabanis et al., 2001). The research hypothesis regarding the impact of income on the level of consumer ethnocentrism has the following form: H3: Consumers with lower income tend to be more ethnocentrically oriented in comparison with consumers with higher income. According to Cutura (2006), gender and income of households did not turn out to be significant, as there is neither difference in the level of ethnocentric tendencies with subjects by gender nor level of income. However, age and education appeared as important characteristics affecting levels of ethnocentric tendencies. The results showed that older subjects, as well as those with lower levels of education, had significantly higher levels of ethnocentric tendencies.

In terms of education level, certain authors (Olsen et al., 1993) stated that persons who were more materialistic and less educated manifested a higher degree of consumer ethnocentrism (Nishina, 1990). Studies of consumer ethnocentrism generally have found that scores on the CETSCALE are related inversely to education and income (Cicic et al., 2003). Grubor and Djokic (2015) state that respondents who graduated from college are less ethnocentric than those with secondary education. In addition, the research by Gasevic et al. (2015) confirmed that the level of consumer ethnocentrism lowers with an increased level of education. Based on aforementioned results, the $\mathrm{H} 4$ hypothesis states: Consumers with higher education level tend to be less ethnocentrically oriented in comparison with consumers with lower education level.

\section{Other Factors that Determine the Ethnocentric Behaviour of Consumers}

Numerous studies have shown that not all consumers are equally ethnocentric. For example, those who tend to be more ethnocentric are people who are less open culturally (Shimp \& Sharma, 1987) and less global minded (Balabanis et al., 2001). Also, consumers who are greater patriots and more conservative, as well as who are collectivist-oriented in comparison with individualists are more ethnocentric (Sharma et al., 1995). 
Studying the phenomenon of consumer ethnocentrism frequently includes the analysis and effect of cosmopolitan behaviour. Cosmopolitan individuals are not affected by prejudice regarding their own culture and their orientations "go beyond any individual cultural setting" (Cannon \& Yaprak, 2002). Consumers become motivated to be more cosmopolitan oriented with the increase in their social status and cultural capacity (Thompson \& Tambyah, 1999).

Consumer ethnocentrism analyzes the impact of membership in a certain group on individual behaviour. For example, if a German consumer prefers cars from his/her own country due to the perception that the Germans are meticulous, detailed, with high labor standards, or because he/she had had a satisfactory previous experience with using similar German products, then the main reason of giving preference to domestic products lies in the relationship between a product and country image. This in itself does not mean that the consumer is ethnocentric and it cannot be expected that the consumer will tend to prefer other unrelated German products in the future. On the other hand, when consumers prefer domestic products for moral reasons such as protection of domestic jobs against competition, then consumer ethnocentrism is considered as the main reason. In this case, it is expected that the consumer will tend to prefer other domestic products. From an ethnocentric consumer point of view, the product has the function of the classification criterion of domestic versus imported products. Therefore, the country of origin data have a significant diagnostic value for ethnocentric consumers. Consumer ethnocentrism launches a motivational process of seeking information about the country of origin (Cutura \& B. Malic, 2016).

While consumer ethnocentrism, national identity and economic nationalism jointly reflect the level of "discrimination against foreign products" (Baughn \& Yaprak, 1996), the main reason for this discriminatory behaviour is the preference of domestic products rather than negativism towards any country individually. Therefore, it is anticipated that such discrimination may affect all foreign products. Consumer animosity, introduced by Klein et al. (1998), on the other hand, refers to consumer negativism towards a particular country due to war, economic or political reasons. Ethnocentrism, as well as associated constructs of animosity and affinity, have a strong impact on consumer attitudes and their purchase behaviour (Auruskeviciene et al., 2012).

Nationalistic emotions influence attitudes towards products and intentions to purchase. Consumer nationalism affects the cognitive evaluation of products and therefore the intention to purchase. This entails that those individuals who have nationalistic intentions perceive the quality of domestic products as higher in comparison to foreign ones (Han, 1989). A significant effect of nationalism and national identity on the level of consumer ethnocentrism in Bosnia and Herzegovina was confirmed by Vida et al. (2008). In the sample of 580 urban consumers, they found that ethnic affiliation has a direct effect on both consumer ethnocentrism and on domestic purchase bias. Bosnians seem to be the most ethnocentric consumers in Bosnia and Herzegovina, followed by Serbs and then Croats. Ethnic affiliation of consumers has a direct effect on both consumer ethnocentrism and on domestic purchase behaviour (Dmitrovic \& Vida, 2009). Research results from 2012 also confirmed that ethnicity is an important factor in the context of B\&H society for overall consumer orientation, towards both the domestic and the imported products. Bosnians are ethnocentric, with a tendency to purchase local products, and evaluate them better. The Croats, on average, are non-ethnocentric and polycentric at the same time, showing a great tendency towards imported products. On the other hand, Serbs have, on average, low ethnocentric tendencies without any signs of polycentrism, which is expected in the case of consumers with low ethnocentric tendencies, who are, in a way, unicentric or oriented towards Serbian products (Cutura, 2012). Furthermore, regarding the influence of nationality on the level of consumer ethnocentrism, the results of a survey among students in Sarajevo in 2016 indicate that, on average, Bosnian students tend be more ethnocentric consumers than Turkish students (Becic, 2016).

Research has shown that non-ethnocentric consumers in Turkey tend to express much more favourable beliefs, attitudes and intentions with regard to imported products than is the case with ethnocentric consumers (Kucukemiroglu, 1999). Ethnocentric tendencies among Korean consumers play an important role in decision-making with regard to a certain product that is a significant source of workplaces and revenue for the local economy (Sharma et al., 1992). Also, when an imported product is perceived as less necessary, ethnocentric tendencies may play a more important role in making purchase decisions (Kucukemiroglu, 1999). Highly ethnocentric consumers often make biased judgments and over-evaluate domestic products unreasonably in comparison with foreign products (Bećić, 2016). Results of a research conducted in Moldova indicated that consumers tended to sustain the local producers in order to help enhance the country's 
economy. But if they could not find local products of good quality, they bought imported products. Also, if the local products were more expensive, then many respondents preferred the imported goods (Cazacu, 2016).

\section{Research Methodology}

This paper emerged as the result of a research conducted between April $15^{\text {th }}, 2016$ and June $13^{\text {th }}, 2016$. The questionnaire method was used for data collection. The sampling method was random. A questionnaire was created and sent electronically to respondents for completion. The questionnaire was sent to 210 e-mail addresses. The response rate was $80 \%$, i.e., 168 respondents sent their replies. Primary data were collected from respondents who belong to various age and gender groups and with different levels of income and education. The sample characteristics are presented in Table 1.

The questionnaire consisted of two parts. The first part of the questionnaire included questions regarding the demographic and socioeconomic characteristics of respondents. These data were used for testing the research hypotheses. The Mann-Whitney $U$ test provided an answer to the question whether men and women differ in the level of consumer ethnocentrism. Also, this test was used to obtain an answer to the question whether there was a difference in the level of consumer ethnocentrism among the people of different age groups and levels of education. The Kruskal-Wallis test was applied to determine whether and how the level of the respondents' income influences consumer ethnocentrism.

The second part of the questionnaire was designed to measure respondents' consumer ethnocentric tendencies. The original measurement of consumer ethnocentrism (CETSCALE) which contained 17 items developed by Shimp and Sharma (1987) was adopted and adapted to determine the level of consumer ethnocentrism in Serbia. Participants were requested to rate the items on a five-point Likert scale $(1=$ strongly disagree and $5=$ strongly agree). The structure of the questionnaire was particularly adapted from the works of Teo, Mohamad and Ramayah (2011) in Malaysia, Mangnale, Potluri and Degufu (2011) in Ethiopia and Chendo (2013) in Nigeria. The five-point Likert scale was used during the implementation of the research conducted by Garg and Jain (2016) in India, with the exception that these authors applied an adapted CETSCALE with 10 statements. Based on the above statements we formed a new dependent variable. The reliability and internal consistency of this scale were also measured using the Cronbach's alpha coefficient.

\begin{tabular}{|c|c|c|}
\hline Gender & $\begin{array}{l}\text { Number of respondents } \\
\qquad(\mathrm{n}=168)\end{array}$ & Percentage (\%) \\
\hline Men & 58 & 34.5 \\
\hline Women & 110 & 66.5 \\
\hline \multicolumn{3}{|l|}{ Age } \\
\hline $19-28$ years & 62 & 36.9 \\
\hline $29-48$ years & 92 & 54.8 \\
\hline $49-58$ years & 8 & 4.8 \\
\hline Over 58 years & 6 & 3.6 \\
\hline \multicolumn{3}{|l|}{ Professional qualifications } \\
\hline Secondary school & 74 & 44.0 \\
\hline College education & 12 & 7.1 \\
\hline University education & 36 & 21.4 \\
\hline M.Sc./PhD & 46 & 27.4 \\
\hline \multicolumn{3}{|l|}{ Income level } \\
\hline Up to 25000 RSD & 54 & 32.1 \\
\hline Between 25000 and 40000 RSD & 28 & 16.7 \\
\hline Between 40000 and 60000 RSD & 50 & 29.8 \\
\hline Between 60000 and 85000 RSD & 26 & 15.5 \\
\hline More than 85000 RSD & 10 & 6.0 \\
\hline
\end{tabular}

Table 1: Sample characteristics $(n=168)$ 
By analysing the data, it was found that females were the prevailing segment in the sample, in comparison with males. It was also evident that the largest number of respondents belonged to the 29-48 years of age category. When it comes to the level of education of the respondents, it was noted that the sample did not include any respondents with lower education level. The largest number of respondents are those who have completed secondary school. The data on income level showed that the majority of respondents realized income of up to 25000 RSD. There was also a large number of respondents with a monthly income amounting to the average net salary in Serbia. The average net salary per employee paid in August 2017 is 47220 RSD (http://www.stat.gov.rs, 2017). The smallest number of respondents were classified in the category that generated an income higher than RSD 85000.

\section{Research Results}

The scale of consumer ethnocentrism (CETSCALE) applied in this research has an internal consistency for measuring the ethnocentric tendencies of Serbian consumers. The resulting value of Cronbach's Alpha coefficient of 0.956 can be considered a reasonably high reliability coefficient which implies that the research results are representative and that a reliable research model was applied. Based on this, it can be assumed that all 17 items used are measuring the same construct (ethnocentrism) and, therefore, a summative measure can be used to represent the ethnocentrism score of the respondents (Chendo, 2013). In addition, the validity of the consumer ethnocentrism concept in the case of consumers in Bosnia and Herzegovina was proven through the high reliability of CETSCALE as a measurement instrument, with Cronbach's Alpha coefficient of 0.95 (Cutura, 2006).

\begin{tabular}{|c|c|c|c|}
\hline Item & $\begin{array}{l}\text { Cronbach's } \\
\text { Alpha if item } \\
\text { deleted }\end{array}$ & Mean & Median \\
\hline $\begin{array}{l}\text { 1. Serbian people should always buy Serbian-made } \\
\text { products instead of imports. }\end{array}$ & 0.954 & 3.761 & 4.000 \\
\hline $\begin{array}{l}\text { 2. Only those products that are unavailable in Serbia } \\
\text { should be imported. }\end{array}$ & 0.954 & 4.047 & 5.000 \\
\hline 3. Buy Serbian-made products. Keep Serbia working. & 0.954 & 4.238 & 5.000 \\
\hline 4. Serbian products first, last and foremost. & 0.953 & 3.559 & 4.000 \\
\hline 5. Purchasing foreign-made products is un-Serbian. & 0.954 & 2.654 & 3.000 \\
\hline $\begin{array}{l}\text { 6. It is not right to purchase foreign products, because it } \\
\text { puts Serbians out of jobs. }\end{array}$ & 0.952 & 3.381 & 3.000 \\
\hline $\begin{array}{l}\text { 7. A real Serbian should always buy Serbian-made } \\
\text { products. }\end{array}$ & 0.951 & 3.095 & 3.000 \\
\hline $\begin{array}{l}\text { 8. We should purchase products manufactured in Serbia } \\
\text { instead of letting other countries get rich off us. }\end{array}$ & 0.953 & 3.654 & 4.000 \\
\hline 9. It is always best to purchase Serbian products. & 0.953 & 3.357 & 3.500 \\
\hline $\begin{array}{l}\text { 10. There should be very little trading or purchasing of } \\
\text { goods from other countries unless out of necessity. }\end{array}$ & 0.953 & 3.142 & 3.000 \\
\hline $\begin{array}{l}\text { 11. Serbians should not buy foreign products, because this } \\
\text { hurts Serbian business and causes unemployment. }\end{array}$ & 0.952 & 3.321 & 3.000 \\
\hline 12. Curbs should be put on all imports. & 0.954 & 3.500 & 4.000 \\
\hline $\begin{array}{l}\text { 13. It may cost me more in the long-run, but I prefer to } \\
\text { support Serbian products. }\end{array}$ & 0.953 & 3.381 & 3.000 \\
\hline $\begin{array}{l}\text { 14. Foreigners should not be allowed to put their products } \\
\text { on our markets. }\end{array}$ & 0.954 & 2.464 & 3.000 \\
\hline $\begin{array}{l}\text { 15. Foreign products should be taxed by higher taxes } \\
\text { heavily to reduce their entry in Serbia. }\end{array}$ & 0.955 & 3.119 & 3.000 \\
\hline $\begin{array}{l}\text { 16. We should buy from foreign countries only those } \\
\text { products that we cannot obtain within our own country. }\end{array}$ & 0.952 & 3.607 & 4.000 \\
\hline $\begin{array}{l}\text { 17. Serbian consumers who purchase products made in } \\
\text { other countries are responsible for putting their fellow } \\
\text { Serbians out of work. }\end{array}$ & 0.952 & 2.940 & 3.000 \\
\hline
\end{tabular}

Table 2: The adapted 17-item CETSCALE 
As may be noted from Table 2, the most pronounced level of consumer ethnocentrism of consumers in Serbia is present in terms of the impact of ethnocentric behaviour on employment (arithmetic mean is 4.238), while the lowest level is present in the statement relating to behaviour regarding the restriction on the import of foreign products (arithmetic mean is 2.464). Research results of this phenomenon in Serbia from 2015, are almost identical. Namely, the most favourable attitude of the respondents is for the item stating that by purchasing Serbian products, Serbian jobs are preserved (arithmetic mean 4.55) whereas the least favorable attitude was for the item stating that the entire import should be limited (arithmetic mean 1.60) (Gasevic et al., 2015). The same results were obtained from a survey conducted in Bosnia and Herzegovina in early 2014 (Beslagic, 2015). Furthermore, results of a survey on consumer ethnocentrism in Bosnia and Herzegovina in 2003 revealed that the result at CETSCALE was, on average, 4.6 and therefore, we can conclude that Bosnian consumers are highly ethnocentric (4.5 and more points at Likert scale mean that the consumers are highly ethnocentrically oriented, while less than 4.5 at the same scale mean that they have low level of ethnocentricity) (Čićić et al., 2003). Although the total result of CETSCALE shows that Bosnian consumers are highly ethnocentrically oriented, the above-mentioned results indicate that they, however, do not mind possessing foreign products, and that they have nothing against import in general (Čićić et al., 2003). In addition, this table presents the values of Cronbach's Alpha coefficients for each statement individually. This means that the table shows how the removal of each item from the scale may impact coefficient alpha. In case any of the numbers in column Cronbach's Alpha is higher than the final value of alpha, this item should be removed from the scale. (Pallant, 2011).

Nonparametric techniques are specific as their hypotheses are not as strict as those of parametric techniques, and they are more suitable for smaller samples or when the collected data have been measured only on ordinal scales (Pallant, 2011). In accordance with the above reasons and given the nature of the available data, non-parametric techniques were applied in this research (Mann-Whitney Test and Kruskal Wallis Test). The Mann-Whitney test was used to obtain information on how the gender, age, and different levels of education characteristics of the respondents affected the level of consumer ethnocentrism. The Kruskal Wallis Test was applied in order to answer the question whether there was a difference in the level of consumer ethnocentrism among people who have different income levels.

When it comes to the impact of gender characteristics the results of the MW test show that $p=0.031<0.05$ we have concluded that the obtained result is statistically significant (not random) i.e., there are differences in the level of consumer ethnocentrism between men and women. Male respondents express a higher level of consumer ethnocentrism ( $M d=3.7059, n=58$ ) compared to female respondents $(M d=3.3529, n=$ 110). Based on these results, it can be concluded that $\mathrm{H} 2$ hypothesis is confirmed.

When it comes to the impact of age differences on the level of consumer ethnocentrism, the results of MW test show that $p=0.883>0.05$, and we have concluded that the obtained results are not statistically significant, i.e., there are no differences in the level of consumer ethnocentrism between two groups of respondents that are the largest in the sample (group aged 29-48, $n=92$ and group aged 19-28 years, $n=62$ ). In that case, the calculation of the median is not performed (Pallant, 2011). It is concluded that the H1 hypothesis does not confirm the statement that older consumers express more ethnocentric behaviour in comparison to younger age categories.

The results of MW test concerning the influence of education level show that the level of significance is $p=$ $0.012<0.05$, so it can be concluded that the results obtained are not random, i.e., that they are statistically significant and that there is a difference in the level of consumer ethnocentrism among respondents with different education levels. The results of the comparison of the two groups of respondents show that a lower degree of consumer ethnocentrism is shown by respondents who have completed higher education levels (university education + master/ magister/doctoral: $M d=3.2353, n=82$ ), and respondents with lower level of professional qualifications are more inclined to buy local products than foreign respondents (secondary school education + college education: $\mathrm{Md}=3.6471, \mathrm{n}=86)$. The obtained results indicate that $\mathrm{H} 4$ hypothesis is confirmed, i.e., that people with higher education level have a lower level of consumer ethnocentrism.

In case of the influence of income level on consumer ethnocentric tendencies, the results of KW test show that $p=0.036<0.05$, which leads to the conclusion that there is statistically significant difference among the groups, i.e., that there is a statistically significant influence of the income criterion on the level of consumer ethnocentrism of the respondents. However, the obtained results show that the highest level is reported by 
respondents who earn an income between 25,000 and 40,000 dinars ( $M d=4.0882, n=28$ ), and the least ethnocentric respondents who earn an income from 40,000 to 60,000 dinars ( $M d=3.2353, n=50)$. It is interesting that respondents who earn the highest income do not exhibit the lowest level of consumer ethnocentrism. What is more, they are the second category that exhibits the highest level of consumer ethnocentrism (respondents who earn an income between 60,000 and 85,000 dinars + respondents who earn an income of over 85,000 dinars: $M d=3,5882, n=36$ ). Also, consumers with the lowest incomes (up to 25,000 dinars) are not consumer ethnocentric the most ( $\mathrm{Md}=3529, \mathrm{n}=54)$. Based on the above, it can be concluded that the $\mathrm{H} 3$ hypothesis is not confirmed, which indicates that consumers with lower levels of income tend to be more ethnocentric compared to those who receive higher incomes.

Discussion and Conclusion

In this research, we have examined the differences in the level of consumer ethnocentrism among different demographic segments. Conceptual hypotheses have been tested on a sample of 168 respondents in Serbia. The results indicate that age differences are not a statistically significant factor of consumer ethnocentrism. This result is not in accordance with the defined $\mathrm{H} 1$ hypothesis. Ethnocentric tendencies are more prevalent among men than women. This result is in accordance with the results of the research of consumer ethnocentrism in the Republic of Serbia (Marinkovic et al., 2011, Gasevic et al., 2015, Grubor \& Djokic, 2015), which contributes to the confirmation of defined H2 hypothesis. It can be said that this research contributes to studies on consumer ethnocentrism that indicate that female and male consumers have different ethnocentric tendencies. The results have also demonstrated that income is a statistically significant factor that determines the ethnocentric behaviour of respondents. However, the highest level of consumer ethnocentrism is not in the group of respondents with the lowest incomes. In this way, hypothesis $\mathrm{H} 3$, according to which consumers with lower income are more ethnocentric, has been disproved. Hypothesis $\mathrm{H} 4$, which refers to the level of education and the effect of this variable on the priority purchase of products of domestic origin has been proven. The highest level of consumer ethnocentrism is expressed among those respondents who have the lowest level of education. The obtained result is in accordance with research results of this phenomenon in the Republic of Serbia (Grubor \& Djokic, 2015; Gasevic et al., 2015).

In general, the results indicate the importance of researching into the demographic characteristics of consumers. The key benefit of including the demographic variables lies in the fact that they are smoothly measurable and as such are easily used for marketing predictions. Therefore, the inclusion of demographic characteristics in studies of consumer behaviour increases their managerial relevancy (Homburg \& Giering, 2001).

The results of this research have several managerial implications. First of all, they provide managers with a detailed understanding of which groups of consumers in Serbia are the most ethnocentric. This market-related information is essential for companies and their segmentation, targeting and positioning strategies. Marketing managers do not perform their tasks well if they do not take into account the tendency of domestic consumers to be ethnocentric. On the other hand, if they assume that all domestic consumers are ethnocentric, they will most certainly create an inappropriate strategy. In general, all results may assist in a better allocation of marketing resources. Resources can be used to emphasize or diminish the origin, depending on whether the company is domestic or not.

The limitation of this research is reflected in the fact that hypotheses are tested only within a certain context, i.e., they are related only to consumers in the city of Novi Sad in Serbia. In addition, the sample size of respondents should be increased and the sample structure must be taken into account, in the sense of proportional representation of respondents from all categories. This limitation is also related to the manner of collecting the data on respondents. Using an electronic questionnaire, we have eliminated the respondents who do not use computers, do not have an Internet access or are simply not informed about this method of data provision. 


\section{REFERENCES}

[1] Altinta, M. H. \& Tokol, T. (2007). Cultural openness and consumer ethnocentrism: an empirical analysis of Turkish consumers. Marketing Intelligence \& Planning, 25 (4), 308 - 325.

[2] Anderson, W.T. \& Cunningham, W.H. (1972). Gauging foreign product promotion. Journal of Advertising Research, 12 (1). 29-34.

[3] Auruskeviciene, V., Vianelli, D. \& Reardon, J. (2012). Comparison of consumer ethnocentrism behavioural patterns in transitional economies. Transformations in Business \& Economics, 11 (2), 20-35.

[4] Balabanis, G., Diamantopoulos, A., Mueller, R.D. \& Melewar, T.C. (2001). The impact of nationalism, patriotism and internationalism on consumer ethnocentric tendencies. Journal of International Business Studies, 32 (1), 157-169.

[5] Bannister, J.P. \& Saunders, J. (1978). UK consumers' attitudes towards imports: the measurement of national stereotype image. European Journal of Marketing, 12 (8), 562-570.

[6] Becic, M. (2016). An Assessment of Consumer Ethnocentrism Tendencies Scale among University Students: The case of Turkish and Bosnian Student. Inquiry: Sarajevo Journal of Society Sciences, 2 (1), 119-130. DOI: 10.21533/isjss.v2i1.57

[7] Beslagic, A. (2015). Ključne determinante potrošačkog etnocentrizma u Bosni i Hercegovini. Marketing, $46(3), 217-226$

[8] Cannon, H.M. \& Yaprak, A. (2002). Will the real world citizen please stand up! The many faces of cosmopolitan consumer behavior. Journal of International Marketing, 10 (4), 30-52.

[9] Caruana, A. (1996). The effects of dogmatism and social class variables on consumer ethnocentrism in Malta. Marketing Intelligence \& Planning, 14 (4), 39-51.

[10] Cazacu, S. (2016). Preference for domestic goods: a study of consumer ethnocentrism in the republic of Moldova. Ecoforum, 5 (1(8)), 295-302.

[11] Chendo, N.A. (2013). Ethnocentric tendencies and the buyer preferences in a developing South-East Nigeria. Global Journal of commerce \& management perspective, 2 (3), 92-97.

[12] Cicic, M., Brkic, N. \& Praso - Krupalija, M. (2003). Consumer animosity and ethnocentrism in Bosnia and Herzegovina: the case of a developing country in a post-war time. Akademija MM, Letn. 6 (10), 59-67.

[13] Cutura, M. (2006). The impacts of ethnocentrism on consumers' evaluation processes and willingness to buy domestic vs. imported goods in the case of Bosnia and Herzegovina. South East European Journal of Economics and Business, 54-63.

[14] Cutura, M. (2012). The influence of ethnicity on consumers' purchase patterns in the context of Bosnia and Herzegovina. Economic research, Special issue (2), 83-102.

[15] Cutura, M., \& Malic, B.K. (2016). Importance of the Country of Origin from the Consumers' Perspective in the Research Context of Bosnia and Herzegovina. Market, 28 (1), 63-78.

[16] Dmitrovic, T. \& Vida, I. (2009). The role of product nationality in purchase behaviour. Economic research, 22 (2), 25-39

[17] Dornoff, R.J., Tankertsley, C.B. \& White, G.P. (1974). Consumers' perceptions of imports. Akron Business and Economic Review, 5 (Summer), 26-29.

[18] Garg, S.K. \& Jain, P.K. (2016). Ethnocentric tendencies in Indian consumers - an empirical study. International Journal of Sales \& Marketing Management Research and Development (IJSMMRD), 6 (1), 9-16.

[19] Gasevic, D., Jovicic, D. \& Vranjes, M. (2015). Potrošački etnocentrizam. Anali poslovne ekonomije, 13, 1-13. DOI: 10.7251/APE1315001G

[20] Good, L.K. \& Huddleston, P. (1995). Ethnocentrism of Polish and Russian consumers: are feelings and intentions related. International Marketing Review,12 (5), 35-49.

[21] Grubor, A. \& Djokic, N. (2015). Determinants of Choice of Global and National Food Products' Brands. Strategic Management, 20 (2), 58-67.

[22] Han, C.M. \& Terpstra, V. (1988). Country-of-origin effects for uni-national and bi-national products. Journal of International Business Studies, 19 (2), 235-255.

[23] Homburg, C. \& Giering, A. (2001). Personal characteristics as moderators of the relationship between customer satisfaction and loyalty - an empirical analysis. Psychology \& Marketing, 18 (1), 43-66.

[24] Josiassen, A., Assaf, A. G. \& Karpen, I.O. (2011). Consumer ethnocentrism and willingness to buy: Analyzing the role of three demographic consumer characteristics. International Marketing Review, 28 (6), 627 - 646. DOI: 10.1108/02651331111181448

[25] Kaynak, E. \& Kara, A. (1996). Consumer ethnocentrism in an emerging economy of Central Asia. American Marketing Association Summer Educators' Conference Proceedings, San Diego, CA, 514-520. 
[26] Klein, J.G., Ettenson, R. \& Morris, M.D. (1998). The animosity model of foreign product purchase: an empirical test in the People's Republic of China. Journal of Marketing, 62(1), 89-100.

[27] Kragulj, D., Parežanin, M., \& Miladinović S. (2017). Consumer ethnocentrism in transitional economies: evidence from Serbia. Sociološki pregled, 51 (1), 59-79

[28] Kucukemiroglu, O. (1999). Market segmentation by using consumer lifestyle dimensions and ethnocentrism: An empirical study. European Journal of Marketing, 33(5/6), $470-487$.

[29] LeVine, R.A. \& Campbell, D.T. (1972). Ethnocentrism: theories of conflict. Ethnic Attitudes and Group Behavior, John Wiley, New York, NY.

[30] Marinkovic, V., Stanisic, N., \& Kostic, M. (2011). Potrošački etnocentrizam građana Srbije. Sociologija, 53 (1), 43-58.

[31] Melnyk, V., Osselaer, S.M.J.V. \& Bijmolt, T.H.A. (2009). Are women more loyal customers than men? Gender differences in loyalty to firms and individual service providers. Journal of Marketing, 73 (July), 82-96.

[32] Mittal, V. \& Tsiros, M. (1995). Does country of origin transfer between brands?". Advances in Consumer Research, 22 (1), 292-296.

[33] Nazlida, M.H. \& Razli, R.C. (2004). Consumer ethnocentrism: the relationship with domestic products evaluation and buying preference. International Journal of Management Studies,11, 29-44.

[34] Netemeyer, R., Durvasula, S. \& Lichtenstein, D. (1991). A cross-national assessment of the reliability and validity of the CETSCALE. Journal of Marketing Research, 28, 320-327.

[35] Nishina, S. (1990). Japanese consumers: introducing foreign products/brands into the Japanese market. Journal of Advertising Research, 30(2), 35-45.

[36] Olsen, J.E., Granzin, K.L. \& Biswas, A. (1993). Influencing consumers; selection of domestic versus imported products: implications for marketing based on a model of helping behavior. Journal of the Academy of Marketing Science, 21(4), 307-321.

[37] Othman, M.N, Ong, F.S. \& Wong, H.W. (2008). Demographic and lifestyle profiles ethnocentric and nonethnocentric urban Malaysian consumers. Asian Journal of Business and Accounting, 1, 5-26.

[38] Pallant, J. (2011). SPSS Priručnik za preživljavanje, Mikro knjiga, Beograd.

[39] Raskovic, M., Ding, Z., Skare, V., Ozretić, Dj., \& Zabkar, D.V. (2016) Comparing consumer innovativeness and ethnocentrism of young-adult consumers. Journal of Business Research, 69 (9), 3682-3686. https://doi.org/10.1016/j.jbusres.2016.03.029

[40] Schooler, R.D. (1971). Bias phenomena attendant to the marketing of foreign goods in the US. Journal of International Business Studies, 2 (1), 71-80.

[41] Shankarmahesh, M.N. (2006). Consumer ethnocentrism: an integrative review of its antecedents and consequences. International Marketing Review, 23 (2), 146-172.

[42] Sharma, S., Shimp, T.A. \& Shin, J. (1995). Consumer ethnocentrism: a test of antecedents and moderators. Journal of the Academy of Marketing Science, 23 (1), 26-37.

[43] Shimp, T.A. \& Sharma, S. (1987). Consumer ethnocentrism: construction and validation of the CETSCALE. Journal of Marketing Research, 24 (3), 280-289.

[44] Tan, C.T. \& Farley, J.U. (1987). The impact of cultural patterns on cognition and intention in Singapore. Journal of Consumer Research, 13 (4), 540-544.

[45] Teo, P.C., Mohamad, O. \& Ramayah, T. (2011). Testing the dimensionality of Consumer Ethnocentrism Scale (CETSCALE) among a young Malaysian consumer market segment. African Journal of Business Management, 5 (7), 2805-2816.

[46] The Republic Statistical Office, Retrieved from http://www.stat.gov.rs/

[47] Thompson, C.J. \& Tambyah, S.K. (1999). Trying to be cosmopolitan. Journal of Consumer Research, 26 (4), 214-240.

[48] Vida, I., Dmitrovic, T., \& Obadia, C. (2008). The Role of Ethnic Affiliation in Consumer Ethnocentrism. European Journal of Marketing, 24 (3/4), 327- 343. http://dx.doi.org/10.1108/03090560810852968

[49] Veljkovic, S. (2009). Uticaj etnocentrizma na potrošače u Srbiji. Marketing, 40 (2), 97-10

Received: 2016-10-26

Accepted: 2017-11-08 


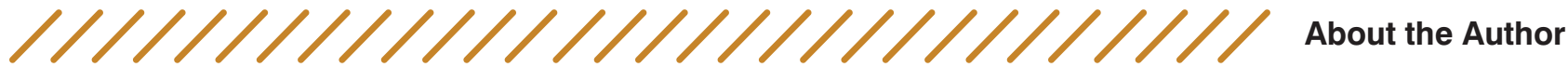

\section{Dragana Gašević \\ Visoka poslovna škola strukovnih studija Novi Sad draganag.vps@gmail.com}

Dragana Gasevic holds a M.Sc. degree from the Faculty of Economics, University of Novi Sad. She is a Ph.D. student at the Faculty of Economics, University of Kragujevac. Since 2012 she has worked as an assistant professor at the Department of Business Economics at the Novi Sad Business School. As author or coauthor, she published a number of papers in scientific journals and national and international conference.

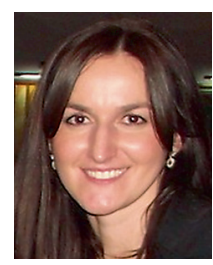

Dragana Tomašević Visoka poslovna škola strukovnih studija Novi Sad dragana.vps@gmail.com

Dragana Tomasevic holds a M.Sc. degree from the Faculty of Economics, University of Novi Sad. She is a Ph.D. student at the Faculty of Economics, University of Kragujevac. Since 2012 she has been engaged as an assistant professor at the Department of Business Economics at the Novi Sad Business School. As author or coauthor, she published a number of papers in scientific journals and national and international conference.

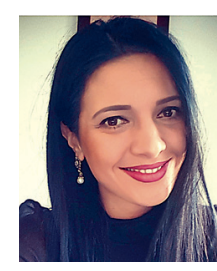

Marija Vranješ Visoka poslovna škola strukovnih studija Novi Sad vranjesmarija.vps@gmail.com

Marija Vranjes holds a M.Sc. degree from the Faculty of Economics, University of Novi Sad. She is a Ph.D. student at the Faculty of Economics, University of Kragujevac. Since 2012 she has been employed as an assistant professor at the Department of Business Economics at the Novi Sad Business School. As author or coauthor, she published a number of papers in scientific journals and national and international conference.

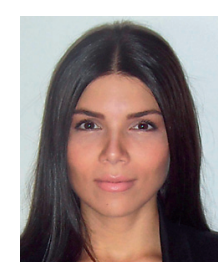

